\title{
Laytime and demurrage implications in voyage charterparties for chemical tankers
}

\section{Christine Padayachee and Micheline Juliana Naude*}

\author{
School of Management, IT \& Governance, \\ College of Law and Management Studies, \\ University of KwaZulu-Natal, \\ Durban, 4000, South Africa \\ Email: christine.padayachee@sasol.com \\ Email: naudem@ukzn.ac.za \\ ${ }^{*}$ Corresponding author
}

\begin{abstract}
Maritime transportation is one of the worst offenders for air, water pollution, and greenhouse gas emissions (GHG). Reducing the emissions in shipping is a common goal for all stakeholders involved in the shipping process. The purpose of this paper was to explore the implications of the laytime and demurrage provisions when using existing charterparties and to suggest how the areas where charterers are exposed to demurrage can be addressed and thus improve sustainability. A comparative analysis was conducted on selected standard voyage charterparties. The findings revealed various areas that do not protect a charterer's interest. It is proposed that in order to solve this challenge a global group consisting of stakeholders be formed to collectively design laytime and demurrage clauses in order to achieve greater sustainability and reduce demurrage. A revised charterparty form for the transportation of chemical liquid bulk chemicals by tankers could then be created.
\end{abstract}

Keywords: laytime; demurrage; voyage charterparties; chemical tankers; maritime; sustainability; sustainable shipping.

Reference to this paper should be made as follows: Padayachee, C. and Naude, M.J. (2021) 'Laytime and demurrage implications in voyage charterparties for chemical tankers', Int. J. Innovation and Sustainable Development, Vol. 15, No. 4, pp.496-516.

Biographical notes: Christine Padayachee is a former Masters' student of the University of KwaZulu Natal. Her study deal with laytime and demurrage implications in voyage charterparties.

Micheline Juliana Naude is an academic in the School of Management, IT \& Governance at the University of KwaZulu-Natal. Her area of expertise is in supply chain management in the areas of purchasing, operations and logistics management. 


\section{Introduction and background}

Unarguably, the maritime industry is of vital importance with total volumes of global trade in 2018, reaching 11 billion tons (UNCTAD, 2019). Over the years, sustainability in the maritime industry has attracted growing attention through sustainable shipping as a consequence of the contribution to global greenhouse gas emissions (GHG) and air pollution in ports. Improving energy efficiency and reducing GHG emissions is key in the development of sustainable shipping (Ahokas, 2019; Wu et al., 2019). Since maritime transportation consumes a significant amount of fuel, it is essential to achieve greater sustainability by considering several environmentally friendly policies such as slow steaming, speed optimisation, reducing waiting time and fuel-efficient vessels (Dea et al., 2017).

Waiting times for various modes of transport, including ships, characterise transport system inefficiencies. Measures to reduce waiting times in ports, are likely to reduce transport GHG emissions and lower costs. A faster vessel turnaround in ports is considered one of the most cost-effective energy efficiency measures available and also reduces pollution in port cities - ports are usually located close to heavily populated areas (Poulsen and Sampson, 2020). Ndikom et al. (2017) posit that non-optimal fixing of demurrage and laytime charges without considering how it affects shippers, sustainability and the cost of goods poses a challenge to sustainable shipping industry development. Therefore, in this paper, we explore the need for a charterparty form specifically designed for the transportation of chemical bulk liquid chemicals, focusing on laytime and demurrage. It is proposed that additional clauses could achieve greater sustainability by reducing waiting times at ports, potentially abating GHG emissions and lowering costs. For example, loading when all tanks are not ready, would reduce waiting time at the ports and lower costs. However, as observed by Poulsen and Sampson (2020) while the reduction of waiting time at the ports has the potential to abate GHG emissions from shipping, the complexity of achieving this should not be underestimated.

A charterparty is an agreement between a ship-owner and a charterer. A charterer can hire part or the whole of a ship from a ship-owner, with or without her non-cargo carrying space, with or without crew, for a limited time or for a voyage, a succession of voyages, or other stated purpose (Hare, 2009). Charterparty agreements govern the relationship between the ship-owner and charterer and determine the obligations of both parties based on the intention and purpose for which the agreement has been entered into. The voyage charterparty is not subject to any statutory regimes and is commonly applicable through the use of standard contract forms (Singh, 2011). This type of agreement is usually negotiated in a free market and is subject to the bargaining powers of the parties (Wilson, 2010).

Currently, there is a limited number of standard charterparties for the shipment of bulk liquid chemicals, with most being created for the oil tanker industry (Voropaeva et al., 2012). Bulk liquid chemicals are high value commodities, carried by supersegregated tankers with very specific, technical requirements for carriage (UNCTAD, 2019). Standard charterparty types do not always cater for the unique requirements and challenges of the bulk liquid chemical shipping environment, for example, different laytime and demurrage. In most cases, additional clauses need to be included to cover the associated risks prevalent in the chemical parcel trade (BIMCO, 2008). Laytime is the period of time that is allowed for the charterer to perform its loading and discharging 
operations; demurrage is the monetary compensation when the charterer uses more time than the period of laytime allowed (Cooke et al., 2014; Schofield, 2005; Tiberg, 2013).

The different aspects of laytime and opposing opinions on its interpretation have been the source of various maritime legal disputes. Clauses in a charterparty may be interpreted differently when determining the period of time that is available for loading and discharging, or when the laytime clock commences, when it is interrupted and when it ceases (Tiberg, 2013). Against this background, the aim of the study was:

- to analyse the existing charterparty forms and to provide insight into the meaning of the provisions of the existing voyage charterparties in terms of laytime and demurrage

- to explore challenges associated when using existing voyage charterparties in the chemical tanker environment

- to determine whether including additional clauses in the forms will address the areas where charterers are exposed to demurrage, and ultimately achieve greater sustainability.

Studies that deal with the evaluation of more recent and modern charterparty forms are limited. Therefore, the findings and recommendations of this study contribute to the existing body of knowledge by providing new insights into the field of laytime and demurrage. Moreover, the implementation of the proposed recommendations could assist charterers in the chemical bulk liquid environment to minimise their demurrage exposure, reduce air pollution in ports, reduce GHG emissions and achieve cost savings.

The paper consists of five parts. The first part provides the introduction and background to this study. Next is a review of literature relevant to the research, followed by an explanation of the research methodology. The fourth part presents the results and the findings and explanation thereof, and the chapter concludes with recommendations and concluding remarks.

\section{Literature review}

Sustainability can be defined as the continuation or survival of the business, which requires management to develop most of its societal engagement in relation to the economic goals of the business. However, sustainability is achieved by a business managing and integrating financial, social and environmental strategies, obligations and opportunities equally (Schaltegger et al., 2012; Arnold, 2017; Rauter et al., 2017). Tackling global warming, protecting ecological support systems, reducing energy and resources as well as maintaining functioning societies are significant challenges for many businesses (Siebenhüner and Arnold, 2007; Arnold, 2018), including stakeholders in the shipping industry. Thus, unsustainable management decisions, neglecting social and environmental issues will prevent businesses from improving in terms of sustainability (Schaltegger et al., 2012; Arnold, 2017).

Sustainability in maritime logistics is important due to the sector's contribution to global GHG emissions and air pollution in port areas (Wu et al., 2019). The International Maritime Organization (IMO) is committed to environmental, social, and economic sustainability in international shipping (Kenton, 2019). Until 2012, $\mathrm{CO}_{2}$ emissions from maritime logistics accounted for $2.2 \%$ of total global GHG emissions. It is forecasted that 
emissions resulting from maritime logistics could grow between $50 \%$ and $250 \%$ by 2050 , primarily due to the growth of the global maritime trade (Wu et al., 2019; IMO, 2018).

\subsection{The voyage charterparty}

In voyage charterparties, laytime and demurrage is a complex issue for charterers and ship-owners. Tanker ship-owners and the charterers, have economic incentives to optimise port calls (Panayides, 2018; Poulsen and Sampson, 2020). Charterers pay freight, which covers aspects such as the speed and fuel consumption of the vessel, the voyage distance and crew costs as well as the market rate of the freight market. Time delays that arise during global shipping activities prevent the owner from fulfilling other intended commercial activities. The evolution of laytime and demurrage clauses led to the introduction of a time meter to cater for possible delays during loading or discharge at ports and to mitigate against losses caused by time delays for the ship-owner (Tiberg, 2013).

In a voyage charter, cargo is transported from one point to another in exchange for a price per tonne of that cargo. The price paid per tonne is referred to as the freight rate and is calculated per unit of shipped cargo. The ship-owner generally pays all the costs and consequently takes the operational and commercial risks (Stopford, 2009).

The following are the commonly used existing standard voyage charterparties:

- $\quad$ ASBATANKVOY (Association of Ship Brokers and Agents Tanker Voyage Charter Party)

- $\quad$ ASBACHEMVOY (Association of Ship Brokers and Agents Chemical Voyage Charter Party)

- $\quad$ BPVOY 5 (British Petroleum Voyage Charter Party 5)

- SHELLVOY6 (Shell Voyage Charter Party 6)

- EXXONMOBILVOY2012 (ExxonMobil Voyage Charter Party 2012)

- BIMCHEMVOY 2008 (Baltic and International Maritime Council Chemical Voyage Charter Party 2008).

The charterparty forms were developed by the major oil companies listed above, who are the ship-owners. Therefore, charterparty forms tend to favour these ship-owners rather than the charterers. The exceptions to this are BIMCHEMVOY 2008 and ASBACHEMVOY.

\subsection{Duties and obligations of owners and charterers}

The main implied obligations for the owner are the undertaking of the seaworthiness of the vessel and reasonable dispatch. To provide a seaworthy vessel is an absolute obligation; seaworthiness includes the physical state of the vessel, the competency of the crew, and the fuel, supplies, necessary equipment and facilities required in the carriage of that cargo (Wilson, 2010). The obligation of reasonable dispatch implies that the vessel will proceed on the voyage, loading and discharging at the agreed time, or within a reasonable time. 
For the charterer, there are also certain obligations that must be fulfilled, such as nominating a safe port and having cargo ready for loading (Irwin, 2013; Steamship Mutual, 1999; Thomas, 2006).

\subsection{Laytime and demurrage}

Laytime is the period of time during which the vessel will be at the charterer's disposal for the loading and unloading of the cargo (Singh, 2011). Failure by the charterer to load within the allowed laytime will result in a breach of the contract, and the ship-owner can claim demurrage at an agreed rate per day. If a breakdown on the ship (e.g., a crane or cargo pump breakdown) causes delayed loading or discharging (longer time in port than that specified in the charterparty), then the charterer can claim from the ship-owner (Poulsen and Sampson, 2020).

It is generally accepted that there are three pre-requisites for laytime to commence. These are:

1 The vessel has to tender a valid notice of readiness (NOR), which confirms that it is legally and physically ready and that laytime may commence. If this does not occur, the ship-owner would not be in a position to earn demurrage (Wilson, 2010).

2 The vessel must have arrived at the destination specified in the Charter (Tanriverdi, 2011). Under a port voyage charterparty, delay risks are borne by the charterers from the moment the ship has arrived at the port (Aspragkathou, 2005; Singh, 2011).

3 The vessel has to be actually ready and in a fit condition to receive or discharge her cargo (Wilson, 2010). This means that the vessel must be in a position where its holds and tanks are clean and ready so as to able to receive and carry the cargo; all necessary documentation must be ready; no laws or regulations can stand in the way of access of the charterer to the vessel, with all port health and documentary requirements being completed in accordance with that specific port regulation (Aspragkathou, 2005).

\subsection{Interruptions and exceptions to laytime}

Most tanker charterparties contain specific exception clauses for certain delays (Baughen, 2015). In terms of laytime and demurrage, exceptions are events or conditions where time does not run against the charterer, and interruptions to laytime are those periods of time that are outside the scope of the laytime. Such issues include the following.

\section{Congestion}

It follows from the Laura Prima ${ }^{1}$ case that the charterparty must contain a clause requiring the charterer to provide a berth that is reachable on the vessel's arrival and, if there is congestion, any time delays in obtaining an available berth will be for the account of the charterer.

Strike

Strike means a stoppage of work on the vessel because of industrial action. Exclusions are partial actions, such as the refusal to work overtime, go-slows or working to rule (Cooke et al., 2014; Schofield, 2005). The ship-owner will not be treated as responsible 
for striking tug-boatmen or pilots under the general law and the charterer would need to have a clause exempting strike action from tug-boatmen and pilots for protection in such a case (Cooke et al., 2014).

\section{Storm}

A storm on the Beaufort scale is a wind force of 10, which is a speed of 48 to 55 knots, with visibility affected and a sea state of extremely tall waves with long overhanging peaks and great patches of foam blown in thick white lines along the surface. Schofield (2005) notes that this definition is intended to describe the weather in an open sea and that it is therefore inappropriate to use it to define the term 'storm' for the purpose of demurrage, which is only likely to be incurred when the vessel is in comparatively sheltered waters. Schofield (2005) observed that since 'storm' has a recognised nautical meaning, a better phrase should be used such as 'severe weather'.

\section{Bunkering}

Bunkering is the supplying and loading of fuel for the ship and includes the shipboard logistics of loading fuel and distributing it among available bunker tanks. In the case of the Stolt Spur $^{2}$ the judges held that in cases where the vessel is unavailable for the charterers' operations because the vessel is used for ship-owners' own operations, demurrage would not be applicable for charterers during this period. Charterers tend to rely on this case when they find that ship-owners are taking bunkers when awaiting berth even though they did not cause any delay.

\subsection{Reachable on arrival}

These words were considered and this principle was established in the case of the Laura Prima. ${ }^{1}$ The characteristics of arriving at the berth are that: (1) it has to be safe; and (2) it has to be reachable on arrival (Davies, 2006; Schofield, 2005). This means that if a berth cannot be reached on arrival, the warranty is broken unless there is some relevant protecting exception.

\subsection{Breakdown of machinery or equipment}

In most charterparties there is a clause for the charterer and the owner indicating what to do when machinery and equipment break down (Wilford et al., 2003). Usually time counting for such a break will be split 50/50. Alternatively, if the breakdown is on the shore or terminal of the charterer the demurrage rate will be halved for that particular period.

\subsection{Fault of the ship-owner}

In cases where loading or discharging is interrupted as a result of a fault by the ship-owner, laytime does not count during this period (Baughen, 2015). In the case of The Union Amsterdam ${ }^{3}$ it is suggested that laytime may be suspended regardless of whether the ship-owner is protected by an exceptions' clause in the charter. 


\subsection{Recommended additional clauses}

Most voyage charterparties contain clauses on common activities that occur on a typical voyage or shipment. These clauses provide the basis of how laytime and demurrage will be evaluated when these activities occur. In some cases, these are included as additional clauses. Examples include loading when all tanks are not ready, early loading, the Conoco weather clause, and shifting between berths. The Conoco weather clause refers to delays in berthing and after berthing caused by bad weather. According to this clause, delays in berthing for loading or discharging or any delays after berthing which are due to weather conditions would count as half laytime or, if on demurrage, at one half demurrage rate (Irwin, 2013).

\section{Research methodology}

\subsection{Approaches used}

Since this is an exploratory and comparative study, a qualitative research design was adopted. Two approaches were used for this study. Firstly, a case study of shipping voyages carrying bulk chemicals from different major trade lanes or chemicals out of the Republic of South Africa (RSA) for a period of 12 months was conducted. Secondly, an exploratory and comparative analysis of the selected standard charterparties was undertaken. This provided insight into the laytime and demurrage implications of these voyage charterparties.

\subsection{Target population}

A target population can be defined as a full set of cases or group members from which a sample is taken (Saunders et al., 2019). The population in this study consisted of existing standard voyage charterparties. For the case study, the current population consists of 9-12 vessels exporting chemicals on a monthly basis. Each vessel loads in the ports of Durban and Richards Bay and, depending on the route, each voyage takes between 2-3 months to complete.

\subsection{Sampling}

There are two sampling techniques available, probability and non-probability sampling. With probability sampling, the chance of each case being selected is known and is equal for all cases. With non-probability sampling, the chance of each case being selected is not known (Saunders et al., 2019; Sekaran and Bougie, 2016). A non-probability sample that conforms to certain criteria is called a purposive sample (Cooper and Schindler, 2006). In this study, a non-probability purposive sampling technique was deemed appropriate because information was obtained from specific target groups (Sekaran and Bougie, 2016). Only data from the latest or most relevant standard voyage charterparties were included in this study. 


\subsection{Sample size}

The geographical area of the study included the major trade lanes for the shipment of chemicals out of RSA (Table 1). These trade lanes were chosen as it was envisaged that they would expose possible trends in particular regions and would be most likely to highlight possible challenges in the chemical tanker trade. The voyage trade lanes and voyage charterparties examined are outlined in Table 1.

Table 1 List of voyage trade lanes and charterparties examined in this study

Voyage trade lanes examined

- Shipments from RSA to India and Middle East

- Shipments from RSA to Far East

- Shipments from RSA to North America

- $\quad$ Shipments from RSA to North West Europe

Voyage charterparties examined

- Asbatankvoy

- Asbachemvoy

- $\quad$ BPVOY4

- Shellvoy6

- $\quad$ Exxonmobilvoy 2012

- $\quad$ Bimchemvoy 2008

Source: Compiled by the authors

\subsection{Data collection}

Data collection is the process of collecting and assessing information for a particular topic. There are two types of data, namely primary and secondary data. Primary data is original data collected by the researcher for the purpose of his or her own study, whilst secondary data has come about because of previous research (Sekaran and Bougie, 2016). In this study, only secondary data was used. The secondary data are standard charterparty forms and the documentation generated from the shipments in the case study.

Each voyage was tracked from the arrival of the vessel at the port of loading to each port of discharge until the voyage was complete. The relevant port sheets, surveyor and vessel agents' reports, and the statements of facts issued at each port were collected and analysed. The laytime and demurrage implications of each of the cases for the different trade lanes were calculated based on the application of each of the voyage charterparties under study. Once the demurrage calculation was performed, the results revealed the charterparties that provide the least exposure. Through observation and interpretation of the elements affecting the demurrage calculation present in the case study, the research objectives were achieved. 


\subsection{Data analysis}

Thematic data analysis was carried out to identify the themes present in the charterparties as well as for the actual shipments. Thematic analysis is defined as the analysis of qualitative data through the use of themes (Quinlan et al., 2015). The steps in thematic analysis include familiarising oneself with the data, generating initial codes, searching for themes, reviewing themes, defining and naming themes, and producing the report (Braun and Clarke, 2013; Neuman, 2011).

As the charterparties stipulate how the actual shipping events in a shipment are applied in terms of laytime and demurrage, it follows that the themes related to both aspects give direction on how these events are to be applied. The meaning and interpretation of the clauses are derived by means of a demurrage calculation. In doing such calculations, any gaps were identified as well as the areas where the provisions in the charterparties correlate with the actual events. The themes include and relate to the exceptions to laytime common in each voyage under study, the commencement of laytime, and their differences. Certain variables or events include shifting, weather delays, when the NOR is tendered, and when laytime ends. This assisted in quantifying the exceptions present in each of the charterparties under investigation since these variables are common in each but have different conditions of application. The same process was followed with the documentation generated from the case study.

\subsection{Data quality control}

Validity refers to the issue of whether the data collected is representative of the concept being studied (Wagner et al., 2012). Validity is the degree to which variances found with a measuring instrument truthfully reflect differences between what is being tested (Sekaran and Bougie, 2016). A reliable method of collecting evidence means that, should any other person deploy the same method at a different stage, it would generate the same results. If repeated by the same person, the same results would be obtained from the research (Wagner et al., 2012).

In this study, reliability and validity considerations were taken into account. For the case study, a demurrage calculation was used. One of the authors is a subject matter expert on demurrage and is equipped to carry out demurrage calculations. The calculations were undertaken using formulas in Microsoft Excel to limit human input errors. Any other person with the same knowledge would arrive at identical results. The existing voyage charterparties under investigation are available on the internet, and the documents may be readily accessed.

\subsection{Ethical considerations}

The University of KwaZulu-Natal granted full ethical clearance approval prior to this study being conducted.

\subsection{Assumptions}

When contracting for carriage of goods in shipping by means of charterparties, there are certain variables that need to be agreed between the parties and to be specified in the charterparty. This is done in order to determine whether demurrage is to be charged. The control assumptions that were used when calculating the demurrage are as follows: 
1 the law applicable is English Law.

2 the vessel arrives within her laycan at the earliest time to commence laytime as stipulated in the charterparty.

3 demurrage rate is $\$ 30,000 /$ day.

4 laytime allowed is $150 / 150$, meaning that, for loading, the laytime allowed is calculated as the tonnage loaded divided by 150 and, for discharging, the laytime allowed is the tonnage discharged divided by 150 .

The information required to perform the calculation was obtained from the documentation generated at the completion of loading or discharging at the port. This documentation is a time log of events that occurred at each port. The demurrage calculation provides details regarding areas that expose charterers to demurrage and the typical unique activities found in chemical shipments as well as the overall impact on demurrage of each charterparty.

\section{Analysis and discussion of the results}

The relevant features of each route found from the documentary analysis in the case study are summarised in Table 2.

Table 2 Features of each route from RSA

\begin{tabular}{|c|c|c|c|c|}
\hline & $\begin{array}{l}\text { India and } \\
\text { Middle East }\end{array}$ & Far East & North America & $\begin{array}{l}\text { North West } \\
\text { Europe }\end{array}$ \\
\hline Load ports & $\begin{array}{c}\text { Durban/ } \\
\text { Richards Bay }\end{array}$ & $\begin{array}{c}\text { Durban/ } \\
\text { Richards Bay }\end{array}$ & $\begin{array}{c}\text { Durban/ } \\
\text { Richards Bay }\end{array}$ & $\begin{array}{c}\text { Durban/ } \\
\text { Richards Bay }\end{array}$ \\
\hline Discharge ports & $\begin{array}{l}\text { Hazira, Kandla, } \\
\text { Jebel Ali }\end{array}$ & $\begin{array}{c}\text { Singapore, } \\
\text { Taichung, Ulsan, } \\
\text { Kaohsiung, } \\
\text { Xiaohudao, Map } \\
\text { Ta Phut }\end{array}$ & $\begin{array}{l}\text { New Orleans, } \\
\text { Freeport, Houston }\end{array}$ & $\begin{array}{l}\text { Antwerp, } \\
\text { Rotterdam }\end{array}$ \\
\hline $\begin{array}{l}\text { Multiple berths } \\
\text { called at each port }\end{array}$ & No & $\begin{array}{c}\text { Yes-Singapore and } \\
\text { Ulsan }\end{array}$ & $\begin{array}{l}\text { Yes-Houston and } \\
\text { New Orleans }\end{array}$ & No \\
\hline \multirow[t]{2}{*}{$\begin{array}{l}\text { No of berths called } \\
\text { at ports }\end{array}$} & Not applicable & $\begin{array}{c}\text { Singapore-up } \\
\text { to } 4 \text {, Ulsan-up to } 2\end{array}$ & Houston-up to 2 & Not applicable \\
\hline & & & $\begin{array}{l}\text { New Orleans-up } \\
\text { to } 3\end{array}$ & \\
\hline $\begin{array}{l}\text { Cargo loaded/ } \\
\text { discharged for } \\
\text { other charterers at } \\
\text { same berths called }\end{array}$ & No & No & No & Yes \\
\hline $\begin{array}{l}\text { All tanks ready at } \\
\text { load port on arrival }\end{array}$ & Yes & Yes & Yes & $\begin{array}{l}\text { No-vessel loads } \\
\text { and discharges } \\
\text { simultaneously }\end{array}$ \\
\hline $\begin{array}{l}\text { Barging/ship to } \\
\text { ship transfer/ } \\
\text { transshipment }\end{array}$ & No & No & No & $\begin{array}{l}\text { Yes-done in } \\
\text { Antwerp and } \\
\text { Rotterdam }\end{array}$ \\
\hline
\end{tabular}

Source: Compiled by the authors 


\subsection{Overview of charterparties}

A basic overview of the differences in each of the charterparties included in this study is presented in Table 3. The differences focus on when each was published and by which body or organisation, and the trade for which it was designed.

Table 3 Overview of charterparties

\begin{tabular}{|c|c|c|c|c|c|c|}
\hline & Asbatankvoy & Asbachemvoy & $\begin{array}{c}\text { Bimchemvoy } \\
2008\end{array}$ & $\begin{array}{c}\text { Exxonmobilvoy } \\
2012\end{array}$ & Shellvoy6 & BPVOY5 \\
\hline $\begin{array}{c}\text { Came into } \\
\text { effect }\end{array}$ & $\begin{array}{c}1969 \text { (original } \\
\text { name } \\
\text { Exxonmobilvoy69 } \\
\text { ) }\end{array}$ & 2008 & 2008 & 2012 & 2005 & 2016 \\
\hline Published by & $\begin{array}{c}\text { Association of } \\
\text { Ship Brokers and } \\
\text { Agents (ASBA) }\end{array}$ & $\begin{array}{c}\text { Association of } \\
\text { Ship Brokers and } \\
\text { Agents (ASBA) }\end{array}$ & $\begin{array}{l}\text { Published by the } \\
\text { Baltic and } \\
\text { International } \\
\text { Maritime } \\
\text { Council } \\
\text { (BIMCO) }\end{array}$ & ExxonMobil & Shell & $\mathrm{BP}$ \\
\hline $\begin{array}{l}\text { Port or Berth } \\
\text { Charterparty }\end{array}$ & Port & Port & Port & Port & Berth & Port \\
\hline Trade & $\begin{array}{l}\text { Designed for oil } \\
\text { and petroleum } \\
\text { trade }\end{array}$ & $\begin{array}{l}\text { Designed to have } \\
\text { broad references } \\
\text { to statutory rules } \\
\text { such as IMO and } \\
\text { MARPOL, which } \\
\text { are common in the } \\
\text { chemical trade, } \\
\text { but still } \\
\text { incorporating the } \\
\text { oil trade clauses }\end{array}$ & $\begin{array}{l}\text { Designed to } \\
\text { incorporate } \\
\text { hazards and } \\
\text { peculiarities of } \\
\text { chemical tanker } \\
\text { trade }\end{array}$ & $\begin{array}{l}\text { Designed for } \\
\text { oil and } \\
\text { petroleum } \\
\text { trade }\end{array}$ & $\begin{array}{l}\text { Designed } \\
\text { for oil and } \\
\text { petroleum } \\
\text { trade }\end{array}$ & $\begin{array}{l}\text { Designed } \\
\text { for oil and } \\
\text { petroleum } \\
\text { trade }\end{array}$ \\
\hline
\end{tabular}

Source: Compiled by the authors

As can be seen from Table 3, only the Bimchemvoy 2008 and Asbachemvoy charterparties are designed for the chemical tanker trade. While the Asbachemvoy charterparty has provisions for statutory rules set out by the International Maritime Organisation (IMO) and the International Convention for the Prevention of Pollution from Ships, 1973 as modified by the Protocol of 1978 (MARPOL), it still incorporates the clauses that are applicable to the oil tanker trade.

\subsection{Summary of results}

For the charterparties under investigation, relevant clauses regarding laytime and demurrage exceptions/interruptions were evaluated on the basis of whether time counts or not, and whether half time counts or was not specified. The provisions of the commencement of laytime as well as when laytime ends were tabulated and summarised.

For each shipment, a demurrage calculation was carried out based on each charterparty, with a total of 138 calculations undertaken. This included the total time 
computation at each port less any time where there are exceptions provided for in the charterparty. For each calculation, the following results were obtained:

1 Demurrage was calculated, and results were ranked according to the smallest demurrage amount to the largest. This was done in order to determine the effects of laytime and demurrage provisions in existing voyage charterparties on the demurrage calculation for chemical tankers. The smallest demurrage amount is ranked from 1 onwards and indicates those charterparties which have provided the least exposure to demurrage.

2 Laytime implications in terms of activities/delays whereby time to count, time not to count or half time to count for each charterparty and the corresponding voyage are quantified according to the days of delay.

\subsection{Exceptions/interruptions to laytime and demurrage}

The exceptions to laytime and demurrage determine when laytime is interrupted and when the demurrage calculation has to be performed. The initial step was to evaluate and compare each charterparty with regard to the stipulations regarding laytime and demurrage exceptions and interruptions. The results of this exercise revealed that the common stipulations are: (1) time awaiting a berth is always for the charterers account; (2) shifting to first berth does not count as used laytime; (3) breakdown of machinery of the vessel does not count as used laytime; and (4) breakdown of machinery at shore or the terminal counts as half laytime.

The results further revealed that each charterparty has varying positions on: (1) weather related phenomena; (2) awaiting daylight; (3) awaiting pilots; and (4) some provisions such as bunkering and ship-to-ship transfers/ barging/ transshipment. The most notable result is that for the Asbatankvoy and Asbachemvoy charterparties, the laytime and demurrage provisions are the same and therefore the demurrage calculation yielded the same result. The only difference is that the Asbachemvoy clauses were changed so as to cater for chemical trades which are necessary for the performance of the voyage.

\subsection{Effects of recommended additional clauses}

The following additional clauses are recommended: (1) loading when all tanks are not ready; (2) despatch; (3) Conoco weather clause; and (4) shifting between multiple berths. The early loading clause could not be evaluated because none of the vessels arrived before her laycan.

\subsection{Loading when all tanks are not ready}

For the RSA to North West Europe route, the vessel arrives in the load port without all tanks being available and ready for loading, since the vessel has to discharge and clean tanks and then load. 
To illustrate the benefit of looking at the effective overall time for loading, this approach was applied to calculate laytime for the first vessel for this route, with the loading in Durban as the first loading port, where this is applicable. This is illustrated in Appendix 1.

When applying the principle of using the effective time taken when loading, the total laytime is the longest time for parcels to complete loading, with time ending when hoses are disconnected. Since Product D (Appendix 1) is the parcel which took the longest to load, the total time counting for charterers would be this time of $51: 45$, adding the time awaiting berth of $7: 35$, with a total time then of $59: 20$. The same value was obtained from first tank ready, which would be to the benefit of the owners. If, however, for Product D (Appendix 1), the tanks were presented last (at the same time as Product G, for example), then the values would be much lower. Measuring from last tank ready benefits charterers with a much lower laytime. The principle of loading when all tanks are not ready is that laytime is allocated to the charterer for the actual time that the cargo was worked, and in this way both parties benefit. The practical benefit is the loading in 'available' tanks instead of waiting for all tanks to be ready.

Appendix 1 illustrates an example of when all tanks are not ready and loading occurs on the tanks that are ready and available. Here the total time is calculated in the load port (Durban) for Vessel 1 on the RSA to North West Europe route. This time includes the congestion period and the loading of each individual product (Product A to Product I). The total Durban Time (loading when all tanks are not ready) is about $60 \mathrm{~h}$ (59 h, $20 \mathrm{~min}$ ) and for Total Durban Time (from first tank ready) the same result is achieved. The Total Durban Time (from last tank ready) is about $45 \mathrm{~h}$ (44 h, $20 \mathrm{~min}$ ).

\subsection{Despatch}

In applying 50\% demurrage rate for voyages where time used was less than time allowed, it was found that about $16-29 \%$ of total demurrage could be recovered. The benefit of this is that the vessel completes her voyage earlier, due to efficient operations by the charterer, thus positioning her in good time for her next voyage and resulting in additional potential revenue earnings for the owner. Charterers benefit from the overall reduction in their total demurrage.

Table 4 presents the total demurrage amount in negative and positive values for each route and each charterparty. The negative amount is the time saving (despatch) and the positive is demurrage incurred.

Table 4 Sum of demurrage or despatch

\begin{tabular}{llc}
\hline \multicolumn{3}{c}{ Sum of demurrage or despatch } \\
\hline Charterparty & Route & Total \\
\hline Asbatankvoy/Asbachemvoy & RSA to Far East & $-\$ 106,668.82$ \\
& RSA to India and Middle East & $\$ 841,731.35$ \\
& RSA to North America & $\$ 1,017,209.98$ \\
& RSA to North West Europe & $-\mathbf{\$ 4 8 4 , 1 6 4 . 2 7}$ \\
Total & & $\mathbf{\$ 1 , 2 6 8 , 1 0 8 . 2 5}$ \\
\hline
\end{tabular}


Table 4 Sum of demurrage or despatch (continued)

\begin{tabular}{llc}
\hline & Sum of demurrage or despatch & \\
\hline Charterparty & Route & Total \\
\hline Bimchemvoy 2008 & RSA to Far East & $-\$ 113,231.32$ \\
& RSA to India and Middle East & $\$ 828,481.35$ \\
& RSA to North America & $\$ 958,012.07$ \\
& RSA to North West Europe & $-\$ 473,919.54$ \\
Total & & $\mathbf{\$ 1 , 1 9 9 , 3 4 2 . 5 6}$ \\
\hline BPVOY5 & RSA to Far East & $-\$ 303,772.98$ \\
& RSA to India and Middle East & $\$ 743,439.68$ \\
& RSA to North America & $\$ 877,303.73$ \\
BPVOY5 Total & RSA to North West Europe & $-\$ 610,226.77$ \\
Exxonmobilvoy 2012 & & $\mathbf{\$ 7 0 6 , 7 4 3 . 6 7}$ \\
\hline Grand total & RSA to Far East & $-\$ 140,460.48$ \\
& RSA to India and Middle East & $\$ 815,210.52$ \\
& RSA to North America & $\$ 958,012.07$ \\
Shellvoy 6 & RSA to North West Europe & $-\$ 485,226.77$ \\
& & $\mathbf{\$ 1 , 1 4 7 , 5 3 5 . 3 3}$ \\
\hline & RSA to Far East & $-\$ 307,981.32$ \\
& RSA to India and Middle East & $\$ 722,127.18$ \\
& RSA to North America & $\$ 839,626.65$ \\
& RSA to North West Europe & $-\$ 602,565.38$ \\
& & $\mathbf{\$ 6 5 1 , 2 0 7 . 1 4}$ \\
\hline
\end{tabular}

Source: Compiled by the authors

Table 5 Despatch as a percentage of actual demurrage

\begin{tabular}{lccc}
\hline Charterparty & $\begin{array}{c}\text { Total actual } \\
\text { demurrage }\end{array}$ & Despatch & $\begin{array}{c}\text { \% Despatch as a percentage } \\
\text { of actual demurrage }\end{array}$ \\
\hline $\begin{array}{l}\text { Asbatankvoy/ } \\
\text { Asbachemvoy }\end{array}$ & $\$ 1,858,941.33$ & $-\$ 295,416.54$ & $16 \%$ \\
Bimchemvoy 2008 & $\$ 1,786,493.42$ & $-\$ 293,575.43$ & $16 \%$ \\
BPVOY5 & $\$ 1,620,743.42$ & $-\$ 456,999.88$ & $28 \%$ \\
Exxonmobilvoy 2012 & $\$ 1,773,222.58$ & $-\$ 312,843.63$ & $18 \%$ \\
Shellvoy 6 & $\$ 1,561,753.83$ & $-\$ 455,273.35$ & $29 \%$ \\
\hline
\end{tabular}

Source: Compiled by the authors 
For the RSA to Far East and RSA to North West Europe routes, in every charterparty, the total demurrage is a negative amount, meaning a time saving or possible despatch amount. By only including the total despatch amount and comparing it with the total actual demurrage for each route, the results in Table 5 are achieved.

Including such a clause allowing any unused laytime saved be calculated at half demurrage rate represents between $16-29 \%$ of total actual demurrage incurred.

\subsection{Conoco weather clause}

A typical Conoco weather clause would be such that delays in berthing for loading or discharging or any delays after berthing which are due to weather conditions will count as half laytime or, if on demurrage, at one half demurrage rate.

Incorporating this clause for the case study, the following results were obtained, as presented in Table 6 .

Table 6 represents all the weather-related delays in days for all the shipments. For the BPVOY5, Bimchemvoy 2008 and Exxonmobilvoy, a further saving of USD 18,000 can be achieved; for the Asbatankvoy/Asbachemvoy, USD 30,900, and for Shellvoy6, USD 35,700, based on their current provisions. Therefore, incorporating this clause would mean additional savings on the demurrage cost for all charterparties.

Table 6 Conoco weather clause

\begin{tabular}{lccccc}
\hline & \multicolumn{5}{c}{ Charterparty } \\
\cline { 2 - 6 } Days of delay & BPVOY 5 & $\begin{array}{c}\text { Asbatankvoy } \\
\text { Asbachemvoy }\end{array}$ & $\begin{array}{c}\text { Bimchemvoy } \\
2008\end{array}$ & $\begin{array}{c}\text { Exxonmobilv } \\
\text { oy 2012 }\end{array}$ & Shellvoy 6 \\
\hline Bad weather-gale & 0.32 & 0.32 & 0.32 & 0.32 & 0.64 \\
force wind & & & & 0.85 & 1.7 \\
Fog & 0.85 & 1.7 & 0.85 & 0.02 & 0.03 \\
Thunderstorm & 0.02 & 0.03 & 0.02 & 0.01 & 0.01 \\
Weather delays & 0.01 & 0.01 & 0.01 & 1.2 & 2.38 \\
Grand total & 1.2 & 2.06 & 1.2 & 30,000 & 30,000 \\
Demurrage rate & 30,000 & 30,000 & 30,000 & & $\$ 35,700$ \\
(\$/day) & & $\$ 30,900$ & $\$ 18,000$ & $\$ 18,000$ & \\
Total demurrage & $\$ 18,000$ & & & & \\
\hline
\end{tabular}

Source: Compiled by the authors

\subsection{Shifting between multiple berths}

Time counting for shifting for all the charterparties in this study is for the charterer's account. Should it be stipulated in a clause that time for shifting to agreed additional berths in the same port should not count as used laytime or demurrage, savings in demurrage will result, as outlined in Table 7. 
Table $7 \quad$ Shifting between multiple berths

\begin{tabular}{llc}
\hline \multicolumn{2}{c}{ Sum of days of delay } \\
\hline Route & Delay & Total days of delay \\
\hline RSA to Far East & 2nd berth shifting & 0.52 \\
& 3rd berth shifting & 1.82 \\
& 4th berth shifting & 0.09 \\
Total & & $\mathbf{2 . 4 3}$ \\
\hline RSA to North America & 2nd berth shifting & 1.88 \\
& 3rd berth shifting & 0.39 \\
Total & & $\mathbf{2 . 2 7}$ \\
\hline Grand total & & $\mathbf{4 . 7 0}$ \\
\hline Demurrage rate/day & & US\$30,000 \\
Shifting to additional berth saving FE & & US\$72,900 \\
Shifting to additional berth saving NA & & US\$68,100 \\
\hline Total saving & US\$141,000 \\
\hline
\end{tabular}

Source: Compiled by the authors

\section{Summary of areas that do not protect charterers}

During the study, a number of operational events where identified where there are no provisions in the charterparties to protect charterers. These operational events were selected as they were found to be common operational activities present in the case study.

Table 8 illustrates the areas or operational events which do not protect charterers' interests and expose them to demurrage, according to the corresponding charterparty.

Table 8 Operational events that do not protect charterers

\begin{tabular}{ll}
\hline Operation & Charterparty \\
\hline Multiple berth discharge & All \\
Awaiting daylight & Asbatankvoy, Asbachemvoy, Bimchemvoy 2008 \\
Awaiting pilots & Asbatankvoy, Asbachemvoy, Bimchemvoy 2008 \\
Weather delays & $\begin{array}{l}\text { Fog, thunderstorm, general weather delays not covered under } \\
\text { Asbatankvoy, Asbachemvoy. These charterparties only cover } \\
\text { storm. }\end{array}$ \\
$\begin{array}{l}\text { Exceptions not including both } \\
\text { laytime and demurrage } \\
\begin{array}{l}\text { Pro rata awaiting time for berth } \\
\text { amongst all charterers }\end{array}\end{array}$ & $\begin{array}{l}\text { Asmurrage, always on demurrage" } \\
\text { Asbatankvoy, Asbachemvoy, Exxonmobilvoy 2012, BPVOY5 }\end{array}$ \\
\hline
\end{tabular}

Source: Compiled by the authors 
It is clear from Table 8, that Asbatankvoy and Asbachemvoy charterparties expose charterers to demurrage in the majority of the identified areas. No charterparties have provisions for multiple berth discharge or shifting between berths. The cost of shifting is borne by either the charterer or owner. However, the actual time for shifting is for the charterer's account.

The Bimchemvoy2008 and Shellvoy6 charterparties are the only charterparties that have provisions for pro-rating awaiting time for berths in cases where the vessel loads or discharges for more than one charterer. This is an important consideration as, if there is more than one charterer, each should share in the congestion period when the berth is occupied by other vessels upon arrival at the berth.

The only weather-related delay that is covered in the Asbatankvoy and Asbachemvoy charterparties is storm. A storm according to the Beaufort scale has a wind force of 10 . Therefore, if ports are closed or operations are stopped for safety reasons when the weather condition is anything other than this, time will count for the charterer.

\section{Conclusion}

In this study, insight was provided into the provisions of the existing voyage charterparties in terms of laytime and demurrage. Each charterparty included in this study was evaluated in terms of when laytime commences and ends, together with any exceptions. The exceptions or interruptions to laytime and demurrage were also considered and compared for similarities and differences in each of the charterparties. In order to gain insight into the provisions of a charterparty, it is recommended that a structure with the inclusion of the themes be applied to allow the simplification and extraction of the relevant information related to laytime and demurrage.

The exploration of the associated challenges when using existing voyage charterparties in the chemical tanker environment was achieved. The challenge when using existing voyage charterparties in the chemical tanker environment lies in the unique differences in the loading operation. Such issues include extensive tank cleaning, special testing of tanks pertaining to the type of product being loaded, and the inserting and blanketing of tanks. Risk of contamination of product is common for high-grade chemicals, but the same level of risk does not exist for the oil and petroleum trades. In the oil trade, large volumes of a few grades are loaded on a vessel. In the chemical trade, there are many different grades loaded on a single vessel, with each product having varying requirements for loading so as to ensure no degradation of the product. Existing charterparties usually do not include consideration of loading when all tanks are not ready to load. Practically, waiting for all tanks to be ready is not feasible due to the additional time spent in the berth which is of no benefit to either charterers or owners.

By including additional clauses, the areas where charterers are exposed to demurrage were addressed. The results of the calculations show the potential savings and provide evidence for the inclusion of additional clauses in the charterparty. The additional clauses that are recommended include loading when all tanks are not ready, despatch; the Conoco weather clause, and shifting between multiple berths. 
Both the inclusion of an additional clause to allow tanks to be loaded as they become ready, and also the net effect of the loading operation computed as time counting for the charterer leads to less time spent in the berth, which will benefit both owners and charterers as they will not be prejudiced by delays in preparing tanks for loading. Furthermore, greater sustainability will be achieved as waiting time at ports will be reduced which is likely to reduce transport GHG emissions and lower costs.

By including a despatch clause where $50 \%$ of time saved is refunded to the charterer is an incentive to achieving a quick turnaround at ports, which is mainly for the owner's benefit. This will enable the ship-owner to have ample time to be positioned for his next charterer. In addition, where operations are efficient in certain ports, the charterer can share in this benefit with monetary compensation.

The Conoco weather clause will cover weather-related delays where the time for that period will count as half laytime and demurrage. This clause can be added if the charterparty of choice does not have any provisions or has only limited provisions for weather-related delays.

For certain routes, it was found that the vessel calls at multiple berths at the same port but none of the charterparties have any provisions for laytime and demurrage for the period of shifting between these berths. If it is relevant to the type of shipment involved, it would be useful to include such a clause. This paper is not without its limitations. In this study, the focus was on the clauses affecting laytime and demurrage for each of the different charterparties. Thus, this limitation presents an opportunity to conduct a further study that takes into consideration the applicability of the entire charterparty on the effectiveness of protecting charterers' interest in the chemical tanker trade and how shipping sustainability can be improved. Legislation has been introduced to govern the safe transportation of hazardous bulk liquid cargo by sea but the requirements that the vessel has to adhere to are not always specified in the charterparties. For example, statutory rules set out by International Maritime Organisation (IMO) and vetting requirements as well as the International Convention for the Safety of Life at Sea (SOLAS) are examples of such regulation.

The contribution of this study is to highlight the need for a revised charterparty form specifically designed for the chemical bulk liquid environment, which will focus on risk minimisation for the charterer in terms of laytime and demurrage, improve energy efficiency and reduce GHG emissions which are key in the development of sustainable shipping. This could be achieved by forming a global group consisting of stakeholders in the chemical tanker trade, who collectively have the responsibility to redesign laytime and demurrage clauses which would benefit all the charterers. Therefore, the results of this study contribute to the existing body of knowledge in the shipping field.

\section{References}

Ahokas, M.M. (2019) Analysis of Voyage Optimization Benefits for Different Shipping Stakeholders, Master's thesis, School of Engineering, Aalto University, Helsinki.

Arnold, M.G. (2017) 'Corporate social responsibility representation of the German water-supply and distribution companies: from colourful to barren landscapes', International Journal of Innovation and Sustainable Development, Vol. 11, No. 1, pp.1-22. 
Arnold, M.G. (2018) 'Sustainability value creation in frugal contexts to foster sustainable development goals', Business Strategy and Development, Vol. 1, No. 4, pp.265-275.

Aspragkathou, D. (2005) A Critical Analysis of the Requirements for the Commencement of Laytime in Voyage Charterparties, PhD thesis, School of Law, University of Birmingham.

Baughen, S. (2015) Shipping Law, 6th ed., Routledge, New York, USA.

BIMCO (2008) BIMCHEMVOY 2008: Voyage Charter Party for the Transportation of Chemicals in Tank Vessels Revised, Retrieved from https://www.bimco.org///media/ Chartering/Document_Samples/Voyage_Charter_Parties/Explanatory_Notes_BIMCHEMVO Y_2008.ashx

Braun, V. and Clarke, V. (2013) 'Teaching thematic analysis: Over-coming challenges and developing strategies for effective learning', The Psychologist, Vol. 26, No. 2, pp.120-123.

Cooke, J., Young, T., Taylor, A., Kimball, J., Martowski, D. and Lambert, L. (2014) Voyage Charters, 4th ed., Informa Law, London, UK.

Cooper D.R. and Schindler, P.S. (2006) Business Research Methods, 9th ed., McGraw-Hill, Boston, USA.

Davies, D. (2006) Commencement of Laytime, 4th ed., Informa Law, London, UK.

Dea, A., Kumara, S.K., Gunasekaranb, A. and Tiwaria, M.K. (2017) 'Sustainable maritime inventory routing problem with time window constraints', Engineering Applications of Artificial Intelligence, Vol. 71, pp.77-95.

Hare, J. (2009) Shipping Law and Admiralty Jurisdiction in South Africa, 6th ed., Juta, Cape Town, South Africa.

IMO (2018) Greenhouse Gas Emissions, Retrieved from: http://www.imo.org/en/OurWork/ Environment/PollutionPrevention/AirPollution/Pages/GHG-Emissions.aspx

Irwin, D. (2013) 'Advanced demurrage workshop', Advanced Demurrage Workshop, September, Cape Town, pp.5-10.

Kenton, W. (2019) International Maritime Organization (IMO), Retrieved from: https://www. investopedia.com/terms/i/international-maritime-organization.asp

Ndikom, O., Theophilus C.N, Buhari, S.O. and Okeke Okechukwu, K. (2017) 'An appraisal of demurrage policies and charges of maritime operators in Nigerian seaport terminals: the shipping industry and economic implications', Naše more, Vol. 64, No. 3, pp.90-99.

Neuman, W.L. (2011) Social Research Methods: Qualitative and Quantitative Approaches, 7th ed., Pearson, London, UK.

Panayides, P.M. (2018) Principles of Chartering, 3rd ed., CreateSpace Publishing, North Charleston, SC, USA.

Poulsen, R.T. and Sampson, H. (2020) 'A swift turnaround? Abating shipping greenhouse gas emissions via port call optimization', Transportation Research Part D, Vol. 86, pp.1-13.

Quinlan, C., Babin, B., Carr, J., Griffin, M. and Zikmund, W.G. (2015) Business Research Methods, 1st ed., Cengage Learning, Andover, UK.

Rauter, R., Perl-Vorbach, E. and Baumgartner, R.J. (2017) 'Is open innovation supporting sustainable innovation? Findings based on a systematic, explorative analysis of existing literature', International Journal of Innovation and Sustainable Development, Vol. 11, Nos. 2-3, pp.271-290.

Saunders, M., Lewis, P. and Thornhill, A. (2019) Research Methods for Business Students, 8th ed., Pearson Education, Harlow, UK. 
Schaltegger, S., Lüdeke-Freund, F. and Hansen, E.G. (2012) 'Business cases for sustainability: the role of business model innovation for corporate sustainability', International Journal of Innovation and Sustainable Development, Vol. 6, No. 2, pp.95-119.

Schofield, J. (2005) Laytime and Demurrage, 5th ed., Informa Law, London, UK.

Sekaran, U. and Bougie, R. (2016) Research Methods for Business. A Skill-Building Approach, 7th ed., John Wiley \& Sons, Chichester, UK.

Siebenhüner, B. and Arnold, M. (2007) 'Organizational learning to manage sustainable development', Business Strategy and the Environment, Vol. 16, No. 5, pp.339-353.

Singh, L. (2011) The Law of Carriage of Goods by Sea, 1st ed., Bloomsbury Professional, Haywards Heath, UK.

Steamship Mutual (1999) Notice of Readiness - Voyage Charter, Retrieved from https://www.steamshipmutual.com/publications/Articles/Articles/Notice_Readiness_1.a sp

Stopford, M. (2009) Maritime Economics, 3rd ed., Routledge, London, UK.

Tanriverdi, C. (2011) The Commercial and Legal Significance of Laytime and Demurrage in English Law and the New Turkish Commercial Code, Retrieved from http://www.hg.org/ article.asp?id $=24183$

Thomas, D.R. (2006) 'The safe port promise of charterers from the perspective of the English common law', Singapore Academy of Law Journal, Vol. 18, No. 97, pp.597-628.

Tiberg, H. (2013) The Law of Demurrage, 5th ed., Thomson Reuters, London, UK.

UNCTAD (2019) Review of Maritime Transport, United Nations, Geneva, Switzerland.

Voropaeva, E., Khamaza, E. and Khamaza, I. (2012) 'Economic assessment of commercial conditions for tanker voyage charter party', Asia-Pacific Journal of Marine Science and Education, Vol. 2, No. 1, pp.85-92.

Wagner, C., Kawulich, B. and Garner, M. (2012) Doing Social Research: A Global Context, McGraw-Hill, London.

Wilford, M., Coghlin, T. and Kimball, J. (2003) Time Charters, Lloyd's of London, London, UK.

Wilson, J.F. (2010) Carriage of Goods by Sea, 7th ed., Pearson Education, New York, USA.

Wu, X., Zhang, L. and Luo, M. (2019) 'Discerning sustainability approaches in shipping', Environment, Development and Sustainability, Vol. 22, pp.5169-5184.

\section{Notes}

${ }^{1}$ Nereide SpA di Navigazione v Bulk Oil International Ltd (The Laura Prima) [1981] 3 All ER 737, [1982] 1 Lloyd's Rep 1.

${ }^{2}$ Stolt Tankers Inc v. Landmark Chemicals SA (The Stolt Spur) [2002] 1 Lloyd's Rep 786.

${ }^{3}$ Blue Anchor Line Ltd v Alfred C Toepfer International GmbH (The Union Amsterdam) [1982] 2 Lloyd's Rep 432. 


\section{Appendix 1: Loading when all tanks are not ready (see online version} for colours)

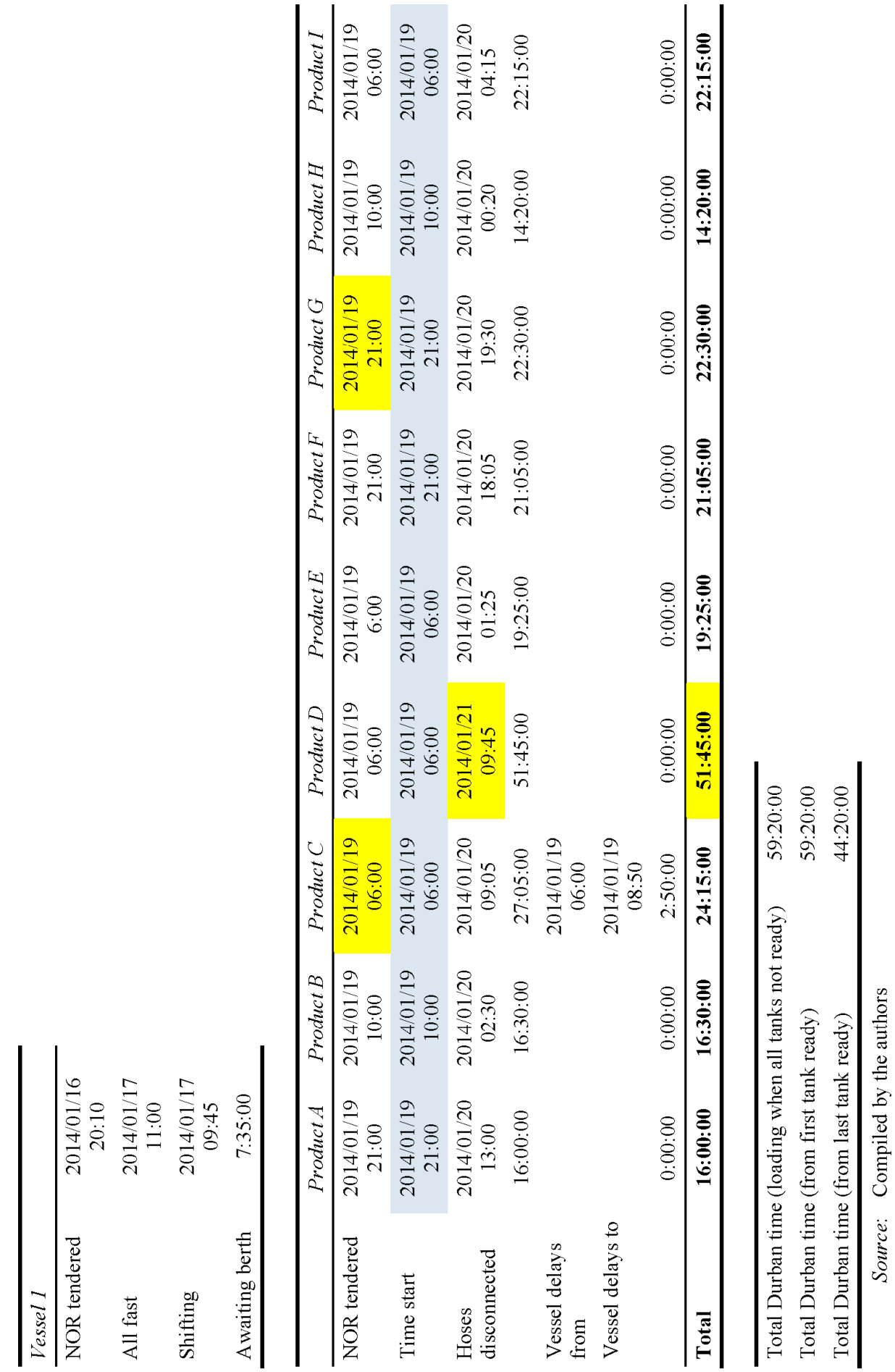

